$$
\text { V }
$$

0

L

U

M

E

12

Social

$P$

A

R

$\mathrm{T}$

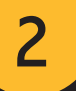

A

$P$

R

I

L

2

0

1
3

Society

A Journal of the Social Policy Association 


\section{Social Policy and Society}

A journal of the Social Policy Association

Managing Co-Editors: Catherine Bochel and Hugh Bochel, School of Social and Political Sciences, College of Social Sciences, University of Lincoln, Brayford Pool, Lincoln LN6 7TS, UK.

Editorial Board:

Sundari Anitha University of Lincoln

Tania Burchardt (ex officio), London School of

Economics and Political Science

Alan Deacon Chair, University of Leeds

Hartley Dean (ex officio), London School of Economics

and Political Science

Nick Ellison (ex officio), University of Leeds

Jackie Gulland University of Edinburgh

Tony Maltby Independent Social Policy Analyst

Alexander Masardo University of Bath

Nasar Meer Northumbria University

Simon Prideaux University of Leeds

Richard Simmons University of Stirling

Andrew Wallace University of Lincoln

Adam Whitworth University of Sheffield

Jay Wiggan Queen's University, Belfast

\author{
International Editorial Advisors: \\ Ayse Idil Aybars Middle East Technical University, \\ Turkey \\ Rik van Berkel Universiteit Utrecht, Netherlands \\ Young Jun Choi Korea University, Korea \\ Adalbert Evers Justus Liebig University Giessen, \\ Germany \\ Neil Gilbert University of California, Berkeley, USA \\ Scott Greer University of Michigan, USA \\ Gabrielle Meagher University of Sydney, Australia \\ Michael J. Prince University of Victoria, Canada \\ Michael Wearing University of New South Wales, \\ Australia
}

Editorial Policy: Social Policy and Society welcomes scholarly papers which analyse any aspect of social policy including any associated teaching and learning issues. In particular, it seeks to encourage contributions which integrate conceptual or theoretical ideas with the use of empirical evidence. Its scope is both international and comparative, and it draws on research and developments in all of the social sciences. (See Editorial, Social Policy and Society, Volume 1, Part 1, 2002.)

Subscriptions: Social Policy and Society is sold together with Journal of Social Policy as a joint subscription only. The annual 2013 institutional electronic-only subscription rate is US \$569 in USA, Canada and Mexico, £333 elsewhere; print plus electronic US $\$ 680$ or $£ 391$; print-only US $\$ 649$ or $£ 381$. Individuals may subscribe at the reduced rates of US $\$ 120$ in USA, Canada and Mexico, £75 elsewhere (print plus electronic). Single parts (Social Policy and Society only) cost US $\$ 168$ or $£ 98$. Prices exclude VAT, but include delivery by air where appropriate. Orders, which must be accompanied by payment, may be sent to a bookseller, subscription agent or direct to the publishers: Cambridge University Press, The Edinburgh Building, Shaftesbury Road, Cambridge CB2 8RU. Orders from the USA, Canada or Mexico should be sent to Cambridge University Press, Journals Fulfillment Department, 100 Brook Hill Drive, West Nyack, New York 10994-2133. EU subscribers (outside the UK) who are not registered for VAT should add VAT at their country's rate. VAT registered subscribers should provide their VAT registration number. Japanese prices for institutions are available from Kinokuniya Company Ltd, P.O. Box 55, Chitose, Tokyo 156, Japan.

Copies of the journal for subscribers in the USA, Canada and Mexico are sent by air to New York to arrive with minimum delay. Periodicals postage paid at New York, NY, and at additional mailing offices. POSTMASTER: send address changes in USA, Canada and Mexico to Journal of Social Policy and Society, Cambridge University Press, 100 Brook Hill Drive, West Nyack, New York 10994-2133.

Copying: This journal is registered with the Copyright Clearance Center, 222 Rosewood Drive, Danvers, MA. 01923, USA (www.copyright.com). Organizations in the USA who are also registered with the CCC may therefore copy material (beyond the limits permitted by sections 107 and 108 of US copyright law) subject to payment to CCC. This consent does not extend to multiple copying for promotional or commercial purposes.

ISI Tear Sheet Service, 3501 Market Street, Philadelphia, Pennsylvania 19104, USA, is authorized to supply single copies of separate articles for private use only.

Organizations authorized by the Copyright Licensing Agency may also copy material subject to the usual conditions.

For all other use, permission should be sought from Cambridge or the American Branch of Cambridge University Press.

This journal is included in the Cambridge Journals Online service which can be found at www.journals.cambridge.org

This journal issue has been printed on FSC-certified paper and cover board. FSC is an independent, non-governmental, not-for-profit organization established to promote the responsible management of the world's forests. Please see www.fsc.org for information.

Printed in the UK by MPG Books Ltd

(C) CAMBRIDGE UNIVERSITY PRESS 2013 